\title{
TINJAUAN AKUNTANSI PNBP BERUPA UANG WAJIB TAHUNAN PADA BADAN PENGUSAHAAN BATAM
}

\author{
I Gusti Bagus Semarajata ${ }^{1)}$; Puji Wibowo ${ }^{2)}$ \\ 1)1302180129_gusti@pknstan.ac.id, Politeknik Keuangan Negara STAN \\ ${ }^{2)}$ puji.wibowo@pknstan.ac.id, Politeknik Keuangan Negara STAN*
}

\begin{abstract}
Annual dues (UWT) are mandatory deposit paid by land user to government institution who authorities the specific zone that is Batam Indonesia Free Zone Authority (BP Batam). UWT is based by developing Batam specific zone where is one of free trade zone in Indonesia. The purpose of research UWT is to find out the contribution of revenue target in BP Batam, collection mechanism, and accounting treatment procedures. As earmarked revenue theory, the UWT receipt creates the optimal of public service with specific in one object. The method of research is literature review, data observation, and interview. The result of research shows, the realization of UWT in last 2 years is almost twice from the target planned, so that it effects to shopping fulfillment for public service which is more optimal. More about of accounting treatment, BP Batam still not fully implemented PSAP 13 in recognition and measurement. It has an impact to presentation of financial statement with dual reporting. PSAP 13 is only implemented on presentation financial statement which is consolidated in financial statement of central government (LKPP).
\end{abstract}

Keywords : Annual dues (UWT), BP Batam, land management rights, PSAP 13, public service agency

\begin{abstract}
Abstrak
Uang Wajib Tahunan (UWT) merupakan setoran yang wajib dibayar oleh pemohon pengelola lahan kepada suatu badan hukum pemerintah yang mengelolaa kawasan khusus yaitu Badan Pengusahaan Batam (BP Batam). Adanya UWT didasari oleh pengembangan kawasan khusus Batam yang telah menjadi kawasan perdagangan bebas. Tujuan penelitian terhadap UWT adalah mengetahui besarnya kontribusi terhadap target pendapatan BP Batam, mekanisme pemungutannya, dan tata cara perlakuan akuntansinya. Berdasarkan teori earmarked revenue, penerimaan dari hasil UWT mewujudkan dalam rangka pengoptimalan pelayanan publik secara spesifik dalam satu objek badan. Metode penelitian yang dilakukan adalah metode studi pustaka, observasi data, dan wawancara. Hasil penelitian menunjukkan, realisasi UWT dalam 2 tahun terakhir mengalami realisasi mencapai hampir 2 kali lipat dari target yang direncanakan, sehingga hal tersebut berdampak pada pemenuhan belanja untuk pelayanan publik yang lebih optimal. Lebih lanjut mengenai perlakuan akuntansinya, BP Batam masih belum sepenuhnya menerapkan PSAP 13 secara penuh dalam pengakuan dan pengukuran. Hal tersebut berdampak dengan timbulnya penyajian laporan keuangan secara berganda. PSAP 13 hanya diimplementasikan dalam penyusunan laporan keuangan yang dikonsolidasi dengan Laporan Keuangan Pemerintah Pusat (LKPP).
\end{abstract}

Kata Kunci : Uang Wajib Tahunan (UWT), BP Batam, Hak Pengelolaan Lahan, PSAP 13, BLU

\section{PENDAHULUAN}

Penerimaan Negara Bukan Pajak (PNBP) adalah pungutan yang dibayarkan oleh orang pribadi atau badan dengan memperoleh manfaat langsung maupun tidak langsung atas layanan atau pemanfaatan sumber daya dan hak yang diperoleh negara, berdasarkan peraturan perundang-undangan, yang menjadi penerimaan pemerintah pusat, di luar penerimaan pajak dan hibah dan dikelola dalam mekanisme anggaran pendapatan dan belanja negara. Hal tersebut diatur dalam Pasal 1 ayat (1) UU No. 9 Tahun 2018 tentang Penerimaan Negara Bukan Pajak (PNBP).

Fungsi PNBP terdiri dari dua jenis yaitu fungsi penganggaran (budgetary) dan fungsi pengaturan (regulatory). Dalam fungsi penganggaran (budgetary), PNBP memiliki andil yang cukup penting dalam pendapatan negara dan penunjang APBN. Di sisi lain, dalam fungsi pengaturan (regulatory), peranan PNBP dapat dikatakan cukup strategis untuk mendukung upaya dari kebijakan pemerintah dalam pengelolaan kekayaan negara termasuk pengoptimalan dalam memanfaatkan sumber daya alam.

PNBP menempati urutan kedua dalam memperoleh pendapatan negara setelah pajak. Objek PNBP dibedakan menjadi enam jenis yaitu pemanfaatan sumber daya alam, pelayanan, pengelolaan kekayaan negara dipisahkan, pengelolaan barang milik negara, pengelolaan dana, 


\section{JURNALKU}

Volume 1 No. 2, Juni 2021

dan hak negara lainnya. Sebagai bagian dari penunjang PNBP, Badan layanan umum (BLU) sangat berperan aktif dalam pengoptimalan Pendapatan Negara melalui pelayanan yang diberikan kepada masyarakat sesuai dengan struktur organisasi yang telah ditetapkan Menteri/Pimpinan Lembaga. Mayoritas pendapatan BLU berasal dari pendapatan pelayanan.

Pengelolaan PNBP sudah diatur di dalam Peraturan Pemerintah Nomor 58 Tahun 2020. Pengaturan pengelolaan PNBP terdiri dari empat jenis rangkaian yaitu perencanaan, pelaksanaan, pertanggungjawaban, dan pengawasan PNBP. Dalam peraturan tersebut hanya pelaksanaan dari Undang-Undang Nomor 9 Tahun 2018 tentang Penerimaan Negara Bukan Pajak dalam rangka peningkatan optimalisasi penerimaan negara dan pelaksanaan pelayanan yang sepandan dengan penerimaan yang diberikan.

Untuk menjalankan tugas dan fungsi sebagai BLU, harus memberikan pelayanan kepada masyarakat yang menerapkan pengelolaan keuangan yang fleksibel, memberikan produktivitas, efisiensi dan efektivitas. Tujuan dari pembentukan BLU adalah memberikan keleluasaan kepada satuan kerja sehingga memberikan layanan kepada masyakarat lebih efektif dan efisien dari hasil pendapatan layanan yang dikelolanya (Waluyo, 2014).

Badan Pengusahaan Batam (BP Batam) didirikan sebagai komponen pemerintah dalam melaksanakan pengembangan kawasan perdagangan bebas dan pelabuhan bebas Batam. Berdasarkan Peraturan Pemerintah Nomor 6 tahun 2011 tentang Pengelolaan Keuangan pada Badan Pengusahaan Kawasan Perdagangan Bebas dan Pelabuhan Bebas Batam, BP Batam merupakan bentuk dari BLU. Pembentukan BP Batam yang sebelumnya bernama Otorita Pengembangan Daerah Industri Pulau Batam (Otorita Batam) berdasarkan Kepres Nomor 41 Tahun 1973. Pulau Batam dipilih menjadi basis daerah ekonomi khusus. Hal itu dikarenakan letak yang sangat strategis yang berhubungan langsung dengan jalur pelayaran internasional antara Selat Malaka dan Laut Cina Selatan. Bahkan, Batam berbatasan langsung dengan dua negara sekaligus seperti Malaysia dan Singapura. Menurut Zenuddin et al (2017), ada alasan Kota Batam dipilih menjadi kawasan perdagangan bebas. Salah satu contohnya yaitu komponen vital dari strategis nasional. Maksud dari komponen tersebut ialah menarik investor asing untuk menanam modalnya di Kota Batam.

Menurut Katadata (2019), BP Batam menempati urutan kelima dalam hal target pendapatan BLU terbesar di tahun 2019 yakni sebesar Rp1.273.307.499.000,00. Realisasinya pada tahun tersebut mencapai 104,59\% atau sebesar nominal Rp1.331.713.643.060,00. Hal tersebut menjadi capaian yang luar biasa mengingat pada laporan keuangan dari dua tahun sebelumnya tidak mencapai $90 \%$ dari realisasi pendapatannya.

Salah satu bagian yang memiliki kontribusi besar dalam penyumbang PNBP BP Batam terbesar yaitu hasil pendapatan dari Kantor Pengelolaan Lahan sebesar Rp575.760.276.090,00 atau sekitar 43,2\% dari jumlah realisasi PNBP BP Batam selama tahun 2019. Realisasi PNBP dari Kantor Pengelolaan Lahan BP Batam bisa dikatakan luar biasa hasil pencapaiannya. Persentase realisasinya dari anggaran mencapai hampir dua kali lipat atau sekitar 191,2\% dari anggaran yang direncanakan sebesar Rp300.000.000.000,00. Realisasi tersebut hampir seluruhnya berasal dari pendapatan Uang Wajib Tahunan (UWT) sebesar Rp562.455.457.928,00.

Pada tahun 2016, terjadinya perubahan tarif UWT yang cukup signifikan dengan kenaikan sebesar $151,7 \%$ hingga $2.640,4 \%$. Hal tersebut merupakan dampak dari diterbitnya Peraturan Menteri Keuangan Nomor 148/PMK.05/2016 tahun 2016 tentang Tarif Layanan BLU Badan Pengusahaan Kawasan Bebas dan Pelabuhan Bebas Batam. Kemudian ditulis kembali peraturan turunannya yaitu Peraturan Kepala (Perka) BP Batam Nomor 19 Tahun 2016. Perubahan tarif tersebut menimbulkan konflik horizontal antara BP Batam dengan elemen masyarakat Kota Batam (Siregar, 2018). Namun konflik tersebut mulai berangsur 


\section{JURNALKU}

Volume 1 No. 2, Juni 2021

kondusif semenjak diterbitkan Perka Nomor 1 Tahun 2017 tentang Perubahan Perka Nomor 148 Tahun 2016.

Sebagai BLU, BP Batam juga dihadapkan pada reformasi pelaporan keuangan yang harus mulai mengadopsi PSAP 13. Disamping itu, terdapat kewajiban mengikuti sistem dan akuntansi pelaporan keuangan BLU sejak 1 Januari 2018. Studi ini bertujuan untuk mengamati perlakuan akuntansi BP Batam dalam berdaptasi dengan perubahan standar akuntansi dan sistem pelaporan keuangan yang baru serta bagaimana menyelesaikan permasalahan.

\section{KAJIAN PUSTAKA}

Penerimaan Negara Bukan Pajak berbeda dengan penerimaan perpajakan, bea cukai dan penerimaan negara yang sah lainnya. Salah satunya ialah fungsi penggunaan atas PNBP yang diperoleh. PNBP diperoleh dari masyarakat atas pelayanan kepada masyarakat. Oleh karena itu, pelayanan yang seharusnya didapatkan oleh masyarakat menjadi tidak adil apabila ditanggung oleh penerimaan perpajakan secara keseluruhan. Hal itu disebabkan setiap pelayanan pemerintah tidak dibutuhkan oleh beberapa elemen karena hal tersebut bukan dari kepentingan masyarakat. Artinya, masyarakat yang memakai layanan pemerintah diwajibkan membayar demi mendapatkan haknya sebagai penerima manfaat dari pelayanan pemerintah. Hasil dari dana yang diperoleh dipergunakan kembali untuk menghasilkan pelayanan yang lebih berkelanjutan sesuai dengan output yang diperoleh. Gambaran dari konsep tersebut dinamakan teori earmarked revenue.

Earmarking didefinisikan sebagai bagian dari implementasi dalam penggunaan penerimaan negara yang diperoleh untuk pembiayaan dari pelayanan publik secara spesifik. Earmarking biasanya digunakan dalam artian penggunaan sumber pajak secara tujuan bersifat tunggal untuk pelayanan yang bersifat tunggal tersebut. Secara kuantitatif, earmarking sangat berperan penting di seluruh penjuru negara bagian Amerika Serikat. Sebagai contoh suatu tingkat pemerintahan lokal, peruntukan dalam pendapatan yang dihasilkan untuk pembiayaan pelayanan yang sangat penting yaitu pelayanan pendidikan (Buchanan, 1963).

Earmarking bisa diimplementasikan dengan baik ketika terdapat hubungan timbal balik antara pembayar dan penyedia manfaat. Itu bisa melindungi dari program prioritas dari pergeseran pembiayaan yang tidak berguna, ketidak efisiensi administratif dan korupsi. Akan tetapi, dibutuhkan sisi efisiensi dari penggunaan manfaat yang telah diberikan. Earmarking biasanya lebih berhasil dalam aktivitas pemerintahan lokal yang membuat pengguna lebih gampang untuk menentukan manfaat yang diterima dan memilih preferensinya dengan cara voting (McCleary, 1991).

Uang Wajib Tahunan (UWT) merupakan uang sewa yang harus dibayarkan oleh pihakpihak atas alokasi lahan yang ada di daerah kawasan berikat Batam kepada BP Batam. Hal tersebut tertuang dalam Pasal 6 Keppres 41 Tahun 1973 tentang Daerah Industri Pulau Batam. Akibat dari penerapan UWT tersebut menyebabkan keseluruan lahan yang berada di kawasan Batam menjadi milik pemerintah pusat yang menunjuk BP Batam sebagai mandat dalam pengelolaan kawasan Batam.

Dalam buku Service marketing, Zeithalm \& JoBitner (2000, dikutip dalam Rohmadin dan Simangunsong, 2018), terdepat tiga jenis pendekatan dalam penetapan harga. Pertama, faktor biaya, yaitu dalam penetapan harga yang berdasar dari biaya yang ditimbulkan, perusahaan menentukan seberapa modal yang dikeluarkan ditambah dengan margin keuntungan yang diperoleh. Kedua, unsur persaingan kompetisi, yaitu menata harga yang telah ditetapkan dari pengamatan persaingan yang ada di suatu pasar yang tersedia. Jika dilihat dari situasi yang ada, terdapat dua sudut pandang yang dilihat yaitu jasa yang disediakan sama pada pasar persaingan sempurna dan jasa yang disediakan lebih sedikit pada pasar oligopoli. Ketiga, aspek permintaan, yang memainkan dari suatu penetapan harga dari perusahaan dengan produk- 


\section{JURNALKU}

Volume 1 No. 2, Juni 2021

produk yang tersedia. pembayaran yang diperoleh dari konsumen merupakan kunci dari faktor permintaan dengan jasa yang telah ada.

Teori keagenan yang biasanya dikenal sebagai principal-agent menjelaskan relasi antara dua atau lebih pihak yang terlibat dalam suatu masalah, ada yang berperan sebagai agen dan prinsipal. Teori tersebut menceritakan terdapat pihak prinsipal yang memberikan otoritas kepada agen untuk menjalankan tugas yang sudah diberikan dari pihak prinsipal (Kivistö, 2008). Fokus dari teori keagenan adalah untuk tujuan prinsipal yang mencoba dalam mengatasi masalah dengan menyeleksi tipe dari agen dan memantau aktivitas dari agen-agennya.

Menurut Arifah (2012, dikutip dalam Varikha \& Wibowo, 2018), teori keagenan didasarkan yang terdiri dari tiga jenis asumsi yaitu asumsi mengenai sifat manusia, asumsi keorganisasian, dan asumsi informasi. Asumsi sifat manusia menjelaskan bahwa manusia cenderung mementingkan diri sendiri, menghindari resiko dan mempunyai batas kapabilitas resiko. Asumsi keorganisasian menjelaskan adanya konflik sesama anggota dalam satu organisasi, efisiensi produktivitas, dan informasi asimetris.

Varikha dan Wibowo (2018) melakukan penelitian terhadap pelaporan keuangan pada Politektik Keuangan Negara STAN yang berbasis akrual. Politeknik Keuangan Negara STAN merupakan bagian dari Badan Layanan Umum. Penelitian tersebut menjelaskan bahwa sebelum diimplementasikan PMK Nomor 220 Tahun 2016, terjadi double reporting dalam satu entitas. Maksud dari double reporting adalah adanya laporan keuangan yang disajikan dalam dua standar yang berbeda seperti PSAK dan PSAP. Hasil dari penelitiannya yaitu PKN STAN mulai mengadopsi single reporting yang hanya berbasis PSAP 13 sejak tahun 2017 dengan meliputi faktor-faktor pendukung seperti regulasi, sumber daya manusia, komunikasi, dan sarana pendukung.

Dewi dan Muliartha (2021) melakukan penelitian pada penerapan PSAP 13 untuk penyajian laporan keuangan Universitas Pendidikan Ganesha dan begitu juga dengan evaluasinya. Universitas Pendidikan Ganesha merupakan bagian dari Badan Layanan Umum sejak tahun 2015 yang tertuang pada Keputusan Menteri Keuangan Nomor 505 tahun 2015. Hasil penelitian tersebut menunjukkan bahwa Universitas Pendidikan Ganesha telah berhasil menerapkan PSAP 13 pada penyajian pelaporan keuangan. Faktor-faktor yang menyebabkannya adalah sinergi antara Sumber Daya Manusia yang berada dalam satu ekosistem Universitas Pendidikan Ganesha untuk memahami lebih lanjut dalam penerapan PSAP 13.

Wartini et al. (2020) melakukan penelitian terhadap pelaksanaan PSAP 13 tentang penyajian laporan keuangan badan layanan umum di perguruan tinggi negeri berupa Universitas Brawijaya. Universitas Brawijaya telah menjadi status BLU sejak tahun 2010. Hasil penelitian tersebut menjelaskan bahwa Universitas Brawijaya telah berhasil mengimplementasikan PSAP 13 pada penyajian laporan keuangan. Akan tetapi terdapat hal yang harus diperbaiki seperti perbaikan sistem pada pendapatan dan belanja supaya memperoleh informasi akrual keseluruhan. Sumber daya manusia dalam penyusunan laporan keuangan sudah memenuhi kompetensi yang cukup berkualitas.

Kesamaan dari tiga penelitan pada tiga paragraf sebelumnya adalah permasalahan dari penyajian laporan keuangan BLU. Penelitian tersebut juga mempermasalahkan penerapan PSAP 13 beserta faktor-faktor yang mendukung dalam penerapannya. Namun dalam penelitian Amirya et al (2012) menunjukkan bahwa pengembangan sistem anggaran dan akuntansi BLU mengakibatkan pada perubahan organisasi yang mencakup nilai manajemen, sumber daya manusia, prosedur, teknologi dan struktur organisasi.

Pengembangan hipotesis mengenai penelitian Penerimaan Negara Bukan Pajak berupa Uang Wajib Tahunan pada Badan Pengusahaan Batam terdiri dari empat rumusan masalah yaitu 1) bagaimana kontribusi Uang Wajib Tahunan terhadap target pendapatan BP Batam? 2) 


\section{JURNALKU}

Volume 1 No. 2, Juni 2021

bagaimana pemanfaatan Uang Wajib Tahunan untuk memenuhi belanja BP Batam? 3) Bagaimana pengakuan, pengukuran, penyajian dan pengungkapan pendapatan Uang Wajib Tahunan?.

\section{METODE}

Penelitian ini adalah riset kualitaitf deskriptif dengan pendekatan studi kasus. Metode pengumpulan data penelitian oleh penulis diklasifikasikan menjadi tiga jenis yaitu metode studi pustaka, metode observasi data, dan metode wawancara. Metode studi pustaka telah dilaksanakan dengan membaca sejumlah jenis pustaka dari sumber literasi yang tersedia mulai dalam bentuk daring maupun non-daring. Contohnya seperti buku, jurnal ilmiah, artikel, media pemberitaan, dan sumber-sumber referensi yang berhubungan riset ini yang berasal dari luar negeri maupun dalam negeri.

Dalam Arikunto (2013), metode observasi merupakan usaha dalam memperoleh data yang dilaksanakan secara sistematis yang didukung oleh prosedur yang memadai. Metode observasi data telah dilakukan dengan menganalisis sumber data yang berhubungan dengan pengelolaan Uang Wajib Tahunan seperti laporan keuangan, rencana kerja, dan rincian data lain yang berkaitan. Penulis telah mendapatkan data yang diperoleh dari BP Batam yaitu berupa Laporan Neraca Saldo periode 1 Desember 2020 sampai dengan 31 Desember 2020, Laporan Keuangan Unaudited 2020, Laporan Keuangan Audited 2017 sampai dengan 2019, Struktur Organisasi BP Batam dan Struktur Organisasi Direktorat Pengelolaan Lahan BP Batam.

Metode wawancara telah dilakukan dengan melakukan sesi wawancara dengan mengajukan pertanyaan lisan kepada pihak-pihak yang berhubungan dengan Uang Wajib Tahunan pada BP Batam. Penulis mewawancari 3 subjek yang berbeda yaitu Kepala Sub Direktorat (Kasubdit) Pelayanan, Informasi lahan, Kepala Sub Bagian Laporan Keuangan Biro Keuangan, dan Staf Sub Bagian Laporan Keuangan Biro Keuangan.

\section{HASIL DAN PEMBAHASAN}

\section{Tinjauan Kontribusi Pendapatan Uang Wajib Tahunan (UWT)}

Realisasi UWT pada Laporan Keuangan BP Batam tahun 2017 audited yaitu sebesar Rp131.183.360.176. Jumlah realisasi tersebut lebih kecil daripada realisasi sebelumnya di tahun 2016 yang sebesar Rp343.896561.023 dengan rasio penurunan sebesar 62\%. UWT yang saat itu masih menjadi bagian pendapatan Kantor Pusat. Jumlah realisasi pendapatan Kantor Pusat yaitu sebesar Rp244.528.963.434, Sedangkan untuk target pendapatan sebesar Rp603.348.170.000 sehingga realisasi terhadap target pendapatan sebesar 40,53\%.

Realisasi Uang Wajib Tahunan (UWT) pada Laporan Keuangan BP Batam tahun 2018 audited yaitu sebesar Rp437.295.127.351. Jumlah realisasi tersebut belum mencapai total target pendapatan Kantor Pengelolaan Lahan selaku tanggung jawab dari pendapatan UWT dan pendapatan lahan lainnya dengan anggaran Rp575.932.922.000. Jumlah realisasi pendapatan Kantor Pengelolaan Lahan yaitu sebesar Rp.449.434.310.542. Rasio realisasi pendapatannya terhadap target yaitu sebesar 78,04\%. Peningkatan pendapatan UWT jika dibandingkan dengan pendapatan UWT tahun sebelumnya yaitu sebesar $233 \%$.

Realisasi Uang Wajib Tahunan (UWT) pada Laporan Keuangan BP Batam tahun 2019 audited yaitu sebesar Rp562.455.457.928. Jumlah realisasi tersebut melebihi dari target pendapatan Kantor Pengelolaan Lahan selaku tanggung jawab dari pendapatan UWT dan pendapatan lahan lainnya. Anggaran Kantor Pengelolaan Lahan untuk Tahun 2019 yaitu sebesar Rp300.000.000.000 sedangkan total realisasi pendapatan yang diperoleh oleh Kantor Pengelolaan Lahan yaitu sebesar Rp575.760.276.090. Rasio realisasi pendapatan terhadap target pendapatan Kantor Pengelolaan Lahan yaitu sebesar 191,92\%. Peningkatan peningkatan 


\section{JURNALKU}

Volume 1 No. 2, Juni 2021

pendapatan UWT jika dibandingkan dengan pendapatan UWT tahun sebelumnya yaitu sebesar $28,62 \%$.

Realisasi Uang Wajib Tahunan (UWT) pada laporan keuangan BP Batam tahun 2020 unaudited yaitu sebesar Rp603.993.810.386. Jumlah realisasi tersebut cukup signifikan jika dibandingkan dengan realisasi tahun sebelumnya. Untuk tahun 2020, semua Pendapatan Kantor Pengelolaan Lahan dilebur kembali menjadi Pendapatan Kantor Pusat yang pernah terjadi di tahun 2017 karena perubahan Struktur Organisasi dan Tata Kerja (SOTK) BP Batam. Anggaran untuk Pendapatan Kantor Pusat yaitu sebesar Rp365.548.083.000 dan realisasi yang diperoleh yaitu sebesar Rp659.850.545.650. Rasio penyerapan anggaran yakni sebesar 180,51\%. Rasio peningkatan pendapatan UWT jika dibandingkan dengan pendapatan UWT tahun sebelumnya yaitu sebesar 7,385\%. Untuk ringkasan realisasi UWT telah tergambar dalam Tabel 1.

Tabel 1. Rincian Realisasi UWT dan Realisasi PNBP Murni BP Batam

\begin{tabular}{|c|c|c|c|}
\hline $\begin{array}{l}\text { Laporan } \\
\text { Keuangan }\end{array}$ & Realisasi UWT & $\begin{array}{l}\text { Jumlah Realisasi } \\
\text { PNBP Murni BP } \\
\text { Batam }\end{array}$ & Presentase \\
\hline 2017 & 131.183 .360 .176 & 974.092 .845 .744 & $13,47 \%$ \\
\hline 2018 & 437.295 .127 .351 & 1.254 .775 .291 .915 & $34,85 \%$ \\
\hline 2019 & 562.455 .457 .928 & 1.330 .736 .108 .567 & $42,27 \%$ \\
\hline 2020 & 603.993 .810 .386 & 1.307 .540 .308 .449 & $46,19 \%$ \\
\hline
\end{tabular}

Sumber: LK BP Batam tahun 2017-2019 (audited) dan LK 2020 (unaudited)

Jika dilihat dari jumlah pendapatan BP Batam yang ada di laporan keuangan, UWT memiliki pendapatan yang cukup mendominasi untuk tahun 2018 dan 2019. Dari gambaran Tabel III.1, Jumlah Pendapatan UWT cenderung fluktuatif. Hal tersebut dikarenakan iklim aktivitas investasi dan perekonomian di Kota Batam yang mengalami pasang surut. Terlebih lagi, realisasi pendapatan UWT mengalami cukup signifikan pada tahun 2019 dan 2020. Hal tersebut dikarenakan banyaknya lahan yang mengalami jatuh tempo pada tahun 2019 dan 2020 . Kemudian, banyaknya lahan yang jatuh tempo diperkuat lagi dengan perkembangan Pulau Batam yang mulai pesat jika ditarik benang merah 30 tahun yang lalu. Banyaknya lahan yang jatuh tempo sesuai dengan definisi dari teori keagenan, yaitu setiap pengelola lahan yang masih tetap mengelola lahan harus memperpanjang kembali masa jatuh temponya

Tinjauan Realisasi Pendapatan atas Pemenuhan Belanja BP Batam

Penerimaan Negara Bukan Pajak (PNBP) Murni BP Batam terdiri dari tujuh jenis uraian beserta dengan realisasi pendapatan yang diperoleh dari tahun 2017 sampai dengan 2019. Dari hasil realisasi tersebut digunakan untuk pemenuhan belanja yang ada di BP Batam. Sumber dana BP Batam berasal dari tiga macam yaitu Rupiah murni, PNBP, dan Pinjaman/Hibah Luar Negeri. Pengesahannya untuk rupiah murni dan PNBP berasal dari KPPN Batam. Pengesahan Pinjaman/Hibah Luar Negeri berasal dari KPPN Khusus Pinjaman dan Hibah. Rincian pengesahan sumber dana yang berasal dari Daftar Pelaksanaan Isian Anggaran (DIPA) Tahun 2017 sampai dengan tahun 2019 digambarkan dalam Tabel 2.

Tabel 2. Rincian Sumber dana DIPA Tahun 2017- 2019 (dalam Rupiah)

\begin{tabular}{rcccc}
\hline DIPA & Rupiah Murni & PNBP & Pinjaman LN & Hibah LN \\
\hline 2017 & 306.367 .600 .000 & 1.158 .197 .829 .000 & 286.240 .000 .000 & - \\
\hline 2018 & 189.264 .759 .000 & 1.522 .343 .342 .000 & 334.551 .432 .000 & - \\
\hline 2019 & 353.961 .896 .000 & 1.516 .611 .489 .000 & 193.621 .568 .000 & - \\
\hline
\end{tabular}

Sumber: DIPA BP Batam Tahun 2017-2019 
Merujuk pada konsep dasar earmarked revenue, penggunaan hasil dari pendapatan BP Batam digunakan untuk kepentingan aktivitas perekonomian khusus dalam Kawasan Batam. Seperti contohnya, pelebaran jalan raya untuk memudahkan transformasi logistik keperluan industri, pemeliharaan Pelabuhan baik internasional maupun domestik, dan lain sebagainya. Dari segi manfaat tersebut, belanja BP Batam sesuai dengan pendekatan cost plus rate yang merujuk pada teori penetapan tarif dasar, yaitu masyarakat memperoleh hasil lebih besar dari layanan yang diberikan.

Belanja BP Batam menurut program dibagi menjadi dua jenis yaitu belanja Program Dukungan Manajemen dan Pelaksanaan Tugas Teknis Lainnya BP Batam dan belanja Program Pengelolaan dan Penyelenggaraan Kawasan Perdagangan Bebas dan Pelabuhan Bebas (PBPB) Batam. Rincian mengenai Belanja BP Batam menurut program dari tahun 2017 sampai dengan tahun 2020 tersaji dalam Tabel 3.

Tabel 3. Realisasi Belanja PNBP Berdasarkan Program

\begin{tabular}{|c|c|c|c|c|}
\hline $\begin{array}{l}\text { Laporan } \\
\text { Keuangan }\end{array}$ & $\begin{array}{l}\text { Program Dukungan } \\
\text { Manajemen dan } \\
\text { Pelaksanaan Tugas } \\
\text { Teknis Lainnya }\end{array}$ & $\begin{array}{l}\text { Program } \\
\text { Pengelolaan dan } \\
\text { Penyelenggaraan } \\
\text { Kawasan }\end{array}$ & Jumlah Realisasi & $\begin{array}{l}\text { Presentase } \\
\text { kenaikan }\end{array}$ \\
\hline 2017 & 737.921 .085 .884 & 795.573 .008 .592 & 1.533 .494 .094 .476 & - \\
\hline 2018 & 641.712 .696 .484 & 727.174 .979 .593 & 1.368 .887 .676 .077 & $-10,73 \%$ \\
\hline 2019 & 681.873 .183 .743 & 883.384 .095 .455 & 1.565 .257 .279 .198 & $14,35 \%$ \\
\hline 2020 & 774.457 .913 .382 & 919.038 .690 .185 & 1.693 .496 .603 .567 & $8,19 \%$ \\
\hline
\end{tabular}

Sumber: LK BP Batam 2017 - 2019 (audited) dan 2020 (unaudited)

Dari hasil rincian realisasi tersebut, akumulatif realisasi belanja BP Batam di tahun 2017 lebih besar ketimbang sumber dana DIPA tahun 2017. Namun di tahun 2018 mengalami penurunan pada akumulatif realisasi belanjanya. Jumlah realisasi belanjanya tidak berbeda jauh dengan realisasi PNBP BP Batam yang selisihnya hanya Rp114.112.384.162,00.

Seperti yang sudah dijelaskan sebelumnya, pendapatan UWT untuk tahun 2018 memberikan dampak yang positif untuk pemenuhan belanja BP Batam. Hal tersebut dikarenakan pendapatan UWT cukup mendominasi ketimbang jenis PNBP BP Batam yang lain. Pada tahun 2018 hingga tahun 2020, realisasi Pendapatan UWT BP Batam menunjukkan presentase lebih dari 30 persen untuk penyerapan pendapatannya kepada realisasi belanja BP Batam. Realisasi pendapatannya sesuai dengan asas manfaat yang penggunaannya digunakan untuk kepentingan umum yang telah dijelaskan pada paragraf sebelumnya. Rincian mengenai penyerapan pendapatan UWT terhadap realisasi belanja BP Batam tergambarkan dalam Tabel 4.

Tabel 3. Perbandingan Realisasi UWT dan Belanja BP Batam

\begin{tabular}{|c|c|c|c|}
\hline $\begin{array}{l}\text { Laporan } \\
\text { Keuangan }\end{array}$ & $\begin{array}{l}\text { Realisasi UWT } \\
\text { BP Batam }\end{array}$ & $\begin{array}{l}\text { Jumlah Realisasi } \\
\text { Belanja BP Batam }\end{array}$ & Presentase \\
\hline 2017 & 131.183 .360 .176 & 1.533 .494 .094 .476 & $8,55 \%$ \\
\hline 2018 & 437.295 .127 .351 & 1.368.887.676.077 & $31,95 \%$ \\
\hline 2019 & 562.455 .457 .928 & 1.565.257.279.198 & $35,93 \%$ \\
\hline 2020 & 603.993 .810 .386 & 1.693 .496 .603 .567 & $35,67 \%$ \\
\hline \multicolumn{3}{|c|}{ Rata-rata presentase UWT dengan Belanja } & $28,02 \%$ \\
\hline
\end{tabular}

Sumber: LK BP Batam 2017 - 2019 (audited) dan 2020 (unaudited)

\section{Pengakuan dan Pengukuran Pendapatan Uang Wajib Tahunan (UWT)}

Pengakuan pendapatan UWT dicatat melalui penjurnalan pada pos-pos kode akun yang sesuai pada Pendapatan Lahan. Berikut merupakan pos-pos akun dari pendapatan lahan beserta 


\section{JURNALKU}

Volume 1 No. 2, Juni 2021

dengan kode akun yang disajikan pada Tabel 5.

Tabel 4. Kode Akun pada Pendapatan Lahan

\begin{tabular}{ll}
\hline \multicolumn{1}{c}{ Kode Akun (COA CODE) } & \multicolumn{1}{c}{ Nama Akun } \\
\hline 4.1 .1 .1 .01 .01 & Pendapatan UWT \\
\hline 4.1 .1 .1 .01 .02 & Pendapatan Pengukuran dan Penetapan Lokasi \\
\hline 4.1 .1 .1 .01 .03 & Pendapatan Pemetaan \& Pengukuran Lahan \\
\hline 4.1 .1 .1 .01 .04 & Pendapatan Administrasi Lahan \\
\hline 4.1 .1 .1 .01 .05 & Pendapatan Revisi Gambar Penetapan Lokasi \\
\hline 4.1 .1 .1 .01 .06 & Pendapatan Rekomendasi Hak Atas Tanah \\
\hline 4.1 .1 .1 .01 .07 & Pendapatan Penggantian Dokumen \\
\hline 4.1 .1 .1 .01 .08 & Pendapatan Pecah dan Gabung Penetapan Lokasi \\
\hline 4.1 .1 .1 .01 .99 & Pendapatan Perijinan Tanah Lainnya \\
\hline
\end{tabular}

Sumber: Neraca Saldo BP Batam periode 1 - 31 Desember 2020

Selain dari kode akun yang tertera pada Tabel 5 terdapat bagian pendapatan lahan yaitu Pendapatan Denda UWT dengan kode akun 4.4.4.1.01.04 yang disajikan pada bagian pendapatan atas Sanksi, Klaim, dan Denda. Berikut merupakan proses jurnal pencatatan UWT yang disajikan dalam Tabel 6.

Tabel 6. Jurnal Pencatatan Pendapatan UWT BP Batam

\begin{tabular}{|c|c|}
\hline Akun & Debit Credit \\
\hline \multicolumn{2}{|c|}{ Jurnal pengakuan pendapatan UWT } \\
\hline Piutang UWT & $\mathrm{XXX}$ \\
\hline Pendapatan UWT & $\mathrm{XXX}$ \\
\hline \multicolumn{2}{|c|}{ Pencatatan koreksi pendapatan UWT } \\
\hline \multicolumn{2}{|c|}{$\begin{array}{l}\text { Dicatat saat penerbitan faktur UWT dan penarikan lahan saat periode laporan } \\
\text { keuangan yang sama }\end{array}$} \\
\hline Pendapatan UWT & $\mathrm{XXX}$ \\
\hline Piutang UWT & $\mathrm{XXX}$ \\
\hline \multicolumn{2}{|c|}{$\begin{array}{l}\text { Dicatat saat penerbitan faktur UWT dan penarikan lahan saat periode laporan } \\
\text { keuangan yang berbeda }\end{array}$} \\
\hline Ekuitas & $\mathrm{XXX}$ \\
\hline Pendapatan yang ditangguhkan & $\mathrm{XXX}$ \\
\hline Piutang UWT & $\mathrm{XXX}$ \\
\hline \multicolumn{2}{|c|}{ Pencatatan pelunasan piutang UWT } \\
\hline Kas di Bank & $\mathrm{XXX}$ \\
\hline Piutang UWT & $\mathrm{XXX}$ \\
\hline \multicolumn{2}{|c|}{ Pencatatan penyesiauan pendapatan UWT yang ditangguhkan } \\
\hline Pendapatan UWT & $\mathrm{XXX}$ \\
\hline Pendapatan yang ditangguhkan & $\mathrm{XXX}$ \\
\hline \multicolumn{2}{|c|}{ Pencatatan penyesuaian pendapatan UWT setiap periode } \\
\hline Pendapatan UWT yang ditangguhkan & $\mathrm{XXX}$ \\
\hline Pendapatan UWT & XXX \\
\hline
\end{tabular}




\section{JURNALKU}

Volume 1 No. 2, Juni 2021

Sumber: diolah dari hasil wawancara

Piutang UWT hanya berlaku selama 60 hari dari tanggal faktur terbit karena menunggu pelunasan UWT oleh pemohon. Hal tersebut menyebabkan tidak adanya skedul umur piutang UWT. Namun saat era pandemi Covid-19, pembayaran UWT diberi kelonggaran untuk mencicil 10 kali untuk setahun sesuai Keputusan Kepala Badan Pengusahaan Kawasan Perdagangan Bebas dan Pelabuhan Bebas Batam Nomor 134 Tahun 2020 tentang Pembayaran Uang Wajib Tahunan Secara Cicilan dan Keringanan Sanksi Perpanjangan Alokasi Lahan pada masa Bencana Nasional Corona Virus Disease 2019. Selain itu juga, terdapatnya keringanan sanksi denda UWT untuk perpanjangan alokasi lahan yang luasnya kurang dari atau sama dengan 250 meter persegi.

Periode keringanannya mencakup beberapa tahap. Pertama, diberi keringanan penuh sanksi keterlambatan atas pengajuan perpanjangan untuk periode 27 Februari sampai dengan 26 Agustus 2020. Kedua, hanya diberikan keringanan $50 \%$ dari sanksi yang seharusnya dibayarkan untuk periode 27 Agustus sampai dengan 26 November 2020. Ketiga, hanya diberikan keringanan $25 \%$ dari sanksi yang seharusnya dibayarkan untuk periode 27 November 2020 sampai dengan 26 Februari 2021.

Perpanjangan UWT hanya berlaku selama 20 tahun saat pemohon mengajukan permohonan untuk perpanjangan lahan. Pengalokasian lahan baru hanya berlaku selama 30 tahun saat pemohon mengajukan permohonan pengalokasian lahan. Namun terdapat pendapatan yang disesuaikan karena jurnal saat pengakuan pendapatan UWT memakai pendekatan jurnal beban terlebih dahulu yang sebelumnya pengakuan pendapatan secara keseluruhan telah diakui. Saat di akhir periode pendapatan tersebut disesuaikan menjadi pendapatan yang ditangguhkan. Jurnal yang dicatat adalah pendapatan yang ditangguhkan tetapi masih diakui untuk periode selanjutnya.

Tarif UWT mengalami perubahan setiap tahunnya. Menurut Perka BP Batam Nomor 9 Tahun 2017, presentase kenaikan tarif UWT yang termasuk pengalokasian lahan baru dan perpanjangan hak atas tanah telah ditetapkan selama $4 \%$ pertahun yang berlaku untuk periode bulan Mei tahun 2022 dan seterusnya. Untuk periode sebelum bulan Mei tahun 2022, telah ditetapkan dalam tabel Perka BP Batam Nomor 9 Tahun 2017. Untuk rincian lebih ringkas bisa melalui aplikasi Kalkulator UWT pada portal BP Batam. Merujuk pada konsep teori penetapan tarif dasar dan asas PNBP, ada yang menyebabkan tarif UWT mengalami kenaikan setiap periode. Penelitian Rohmadin dan Simangunsong (2018) yang merujuk pada teori penetapan tarif dasar menjelaskan ada tiga jenis pendekatan dalam penetapan harga yaitu biaya, kompetisi dan permintaan. Dalam sesi wawancara kepada Kasubdit Pelayanan dan Informasi Lahan, Bapak Yarmanis. Beliau mengatakan kenaikan tersebut dipengaruhi oleh pengembangan investasi yang sedang berkembang. Terdapat relasi yang berkaitan mengapa kenaikan tarif UWT terjadi yaitu faktor biaya dan permintaan. Biaya yang dimaksud adalah besarnya belanja yang dikeluarkan dalam pengembangan sarana dan prasarana yang ada di Kota Batam. Kemudian permintaan yang dimaksud adalah besarnya permintaan penetapan lahan di Batam yang akan digunakan secara produktif oleh pengelola.

Merujuk pada asas PNBP yang didasari oleh asas keadilan dan asas daya pikul, terdapat perbedaan tarif UWT setiap zona. Berdasarkan hasil wawancara dengan Bapak Yarmanis, beliau mengatakan terdapat intensitas aktivitas perekonomian yang berbeda ruang lingkupnya pada setiap zona dan penggunaannya. Pada perbedaan setiap zona didukung kuat oleh analisis penulis yang telah lama menetap di Kota Batam karena intensitas lingkungan aktivitas bisnis yang berbeda.

\section{Penyajian dan Pengugkapan}

Penyajian Pendapatan BP Batam dibagi menjadi empat macam yaitu pendapatan usaha, pendapatan hibah, pendapatan APBN, dan pendapatan usaha lainnya. Pendapatan Kantor Pusat 


\section{JURNALKU}

Volume 1 No. 2, Juni 2021

dibagi lagi menjadi dua jenis yaitu pendapatan dari perijinan dan pendapatan retribusi. Sejak tahun 2020, pendapatan Kantor Pengelolaan Lahan kembali dileburkan menjadi bagian dari Pendapatan Kantor Pusat. Hal tersebut dikarenakan oleh perubahan Susunan Organisasi dan Tata Kerja (SOTK) yang ada di BP Batam.

Penyajian Laporan Keuangan BP Batam dikategorikan menjadi dua macam, yaitu penyajian laporan keuangan yang mengikuti PSAK dan laporan keuangan yang sudah disesuaikan dengan PSAP. Penyajian yang berstandar ganda akan menimbulkan dual reporting dalam satu BLU. Pembahasan mengenai dual reporting akan dibahas pada subbagian bagiansubbab selanjutnya.

Penyajian Laporan Keuangan dengan basis PSAK terdiri dari tiga jenis pelaporan yaitu laporan aktivitas, laporan arus kas, dan laporan posisi keuangan. Aplikasi yang digunakan dalam proses penyajian basis PSAK dilakukan dengan Finance and Billing Management System (FBMS). Untuk menyajikan dalam bentuk PSAP, dilakukan perolehan data dari FBMS dan kemudian diinput dalam microsoft excel. Setelah dilakukan penginputan, dilakukan konversi secara manual sesuai dengan PSAP yang berlaku. Konversi hanya dilakukan untuk bagian laporan operasional dan neraca.

Penelitian Varikha dan Wibowo (2018) menjelaskan bahwa terdapat problematika dalam praktik penyusunan dual reporting. Penelitian tersebut merujuk kepada PKN STAN sebelum tahun anggaran 2017, masih menyusun laporan yang berbasis PSAK maupun PSAP. Hal tersebut mengacu pada ketentuan PMK Nomor 76 Tahun 2008 yang menjadi dasar pedoman akuntansi BLU. Pada saat itu, pelaporan berbasis PSAK dilakukan dengan alasan untuk memenuhi kebutuhan informasi akrual yang saat itu PSAP belum bisa mengakomodir informasi akrual dan masih berbasis kas, Sehingga terjadinya ketidakefisienan dalam penyusunan laporan keuangan. Untuk tahun anggaran 2017, PKN STAN berhasil menyusun laporan keuangan yang mengacu pada PSAP nomor 13, sehingga PKN STAN hanya berfokus dalam penyajian single reporting. Hal tersebut searah dengan PMK Nomor 220/PMK.05/2016 Tentang Sistem Akuntansi dan Pelaporan Badan Layanan Umum. Merujuk pada penelitian tersebut, terdapat faktor-faktor yang mendukung implementasi dalam PSAP 13 mengenai Penyajian Laporan Keuangan Badan Layanan Umum yaitu terdiri dari regulasi, sumber daya manusia, komunikasi, dan sarana pendukung.

Penulis telah melakukan sesi wawancara kepada Ibu Lany Amalia Selaku Kepala Sub Bagian Laporan Keuangan Biro Keuangan BP Batam mengenai dual reporting pada penyajian laporan keuangan BP Batam. Hasil analisis penulis dari hasil wawancara beliau menunjukkan bahwa terdapat faktor-faktor BP Batam masih mempertahankan PSAK sebagai dasar dari proses pengakuan pendapatan dan biaya dalam BP Batam. Faktor tersebut mencakup dalam implementasi PSAP 13 dari penelitian Varikha dan Wibowo (2018), yang meliputi beberapa aspek. Pertama, dari sisi regulasi, BP Batam masih menerapkan Peraturan Kepala BP Batam Nomor 6 Tahun 2013 tentang Sistem Akuntansi Keuangan. Pada peraturan tersebut masih terdapat perubahan-perubahan minor untuk pengakuan pendapatan dan pembiayaan karena mengikuti dari SOTK BP Batam yang berubah setiap waktunya.

Kedua, ditinjau dari faktor SDM yang ada dalam BP Batam cukup banyak karena untuk menunjang unit-unit kerja yang ada dalam aktivitas BP Batam. Unit kerja yang cukup banyak dan bervariatif mengakibatkan penyesuaian untuk PSAP memakan waktu lebih lama. Ketiga, dari aspek komunikasi masih menjadi pertimbangan untuk bertransformasi ke dalam PSAP. Hal tersebut karena unit kerja yang banyak dan bervariatif sehingga dibutuhkan kekompakan dalam pelaksanaannya apabila terwujud. Keempat, dari sisi sarana pendukung, pada bagian sistem pengelolaan keuangan, BP Batam masih lebih dominan memakai sistem aplikasi Finance Billing Management Systems (FBMS) yang masih berstandar pada PSAK. 


\section{JURNALKU}

Volume 1 No. 2, Juni 2021

Dalam proses audit, Laporan Keuangan hanya diperiksa pada basis PSAP saja melalui BPK. Hal tersebut dalam penelitian Varikha dan Wibowo (2018) menjelaskan bahwa laporan keuangan yang berbasis PSAK hanya diaudit oleh Kantor Akuntan Publik (KAP) melalui mekanisme lelang. Dengan demikian, proses pelaporan keuangan BP Batam belum sepenuhnya dapat menerapkan sistem pelaporan dan keuangan yang single reporting berbasis PSAP namun ternyata masih mempertahankan laporan keuangan berbasis PSAK.

\section{PENUTUP}

\section{Simpulan}

UWT pada BP Batam bersifat cukup unik. Dikarenakan BP Batam selaku Badan Hukum Pemerintah yang mempunyai mandat dalam mengelola lahan yang ada di Kota Batam. Hal tersebut menyebabkan tidak ada individu ataupun badan hukum selain BP Batam yang mempunyai hak milik penuh seperti yang terjadi pada kebanyakan daerah lain di Indonesia.

Kontribusi Pendapatan UWT terhadap jumlah realisasi pendapatan yang ada di BP Batam cukup mendominasi dibandingkan dengan jenis pendapatan lain yang ada pada unit-unit kerja BP Batam. Untuk periode pembukuan tahun 2018 hingga tahun 2020, persentase realisasi Pendapatan UWT terhadap jumlah realisasi PNBP BP Batam yaitu sebesar 30\% keatas.

Pemanfaatan UWT dalam memenuhi belanja BP Batam cukup berperan penting. Hal tersebut merujuk pada pembahasan sebelumnya mengenai bahwa presentase antara realisasi Pendapatan UWT terhadap Realisasi Belanja BP Batam yaitu sebesar 30\% keatas untuk periode tahun 2018 hingga tahun 2020. Belanja tersebut dialokasikan dalam pemenuhan aktivitas BP Batam demi menunjang aktivitas perekonomian dalam suatu kawasan perdagangan bebas di Indonesia.

Pengakuan dan pengukuran Pendapatan UWT dilakukan dengan basis PSAK. Hal tersebut dikarenakan unit kerja yang cukup banyak sehingga dibutuhkan sinergi yang lebih matang dalam perencanaannya. Terlebih sistem aplikasi yang digunakan yaitu Finance Billing Management Systems (FBMS) yang merujuk pada basis PSAK. Kemudian membutuhkan waktu yang lebih banyak untuk bertransformasi ke basis PSAP. Sehingga penyajian laporan keuangan pada BP Batam menjadi dual reporting. Penyajian laporan keuangan pertama kali memakai basis PSAK yang diambil terlebih dahulu dari sistem FBMS. Kemudian untuk merubah dalam bentuk PSAP, dilakukan konversi secara manual melalui Microsoft Excel.

\section{Saran}

Dalam pengakuan dan penyajian berupa pendapatan dan penyajian, BP Batam seharusnya melaksanakan basis akrual pada PSAP secara penuh. Hal tersebut dikarenakan BP Batam bisa menyajikan laporan keuangan secara single reporting yang mendukung pada efisiensi dan efektivitas kinerja BP Batam.

Untuk menunjang basis PSAP secara penuh, dilakukan perombakan sistem secara penuh yang dimaknai dengan reformasi pelaporan pada BP Batam. Ditambah lagi diperlukan pendidikan dan pelatihan dalam menyiapkan basis PSAP secara penuh. Akan tetapi dalam menunjang pengimplementasinya, dibutuhkan waktu dan biaya yang tidak sedikit. Untuk pemeriksaan penyajian laporan keuangan dalam bentuk PSAK sebelum dikonversi menjadi PSAP, dilakukan audit oleh Kantor Akuntan Publik (KAP) yang telah ditunjuk.

Riset ini menggunakan pendekatan studi kasus sehingga tidak bisa dilakukan generalisasi atas praktik akuntansi BLU pada satker BLU di tanah air. Penelitian mendatang diharapkan dapat memberikan gambaran yang lebih utuh mengenai praktik akuntansi BLU pada K/L lain atau bahkan pada BLU daerah. Pada saat masa yang akan mendatang, penulis memberikan saran ketika penulisan ini dijadikan sumber referensi untuk penulis lainnya dengan subjek yang sama yaitu harus mencermati sistem kinerja BLU mengenai pelayanan dalam 


\section{JURNALKU}

Volume 1 No. 2, Juni 2021

kawasan khusus. Hal itu dikarenakan BP Batam mempunyai karakteristik yang cukup kompleks dalam hal pelayanan kawasan khusus.

\section{DAFTAR PUSTAKA}

Amirya, M., Djamhuri, A., \& Ludigdo, U. (2012). Pengembangan Sistem Anggaran dan Akuntansi Badan Layanan Umum Universitas Brawijaya: Perspektif Institusional. Jurnal Akuntansi Multiparadigma, 3(3), 343-356. https://doi.org/10.18202/jamal.2012.12.7166

Arikunto, S. (2013). Prosedur Penelitian. Rineka Cipta.

Badan Pengusahaan Batam. (n.d.). Napak tilas pembangunan Batam dalam sejarah Badan Pengusahaan Batam. Diakses tanggal 22 Mei 2020, dari https://bpbatam.go.id/profil/latar-belakang/

Badan Pengusahaan Kawasan Perdagangan Bebas dan Pelabuhan Bebas Batam. (2018). Laporan Keuangan Badan Pengusahaan Batam untuk Periode yang Berakhir 31 Desember 2017. Batam: Badan Pengusahaan Kawasan Perdagangan Bebas dan Pelabuhan Bebas Batam.

Badan Pengusahaan Kawasan Perdagangan Bebas dan Pelabuhan Bebas Batam. (2019). Laporan Keuangan Badan Pengusahaan Batam untuk Periode yang Berakhir 31 Desember 2018. Batam: Badan Pengusahaan Kawasan Perdagangan Bebas dan Pelabuhan Bebas Batam.

Badan Pengusahaan Kawasan Perdagangan Bebas dan Pelabuhan Bebas Batam. (2020). Laporan Keuangan Badan Pengusahaan Batam untuk Periode yang Berakhir 31 Desember 2019 (Audited). Batam: Badan Pengusahaan Kawasan Perdagangan Bebas dan Pelabuhan Bebas Batam.

Badan Pengusahaan Kawasan Perdagangan Bebas dan Pelabuhan Bebas Batam. (2021). Laporan Keuangan Badan Pengusahaan Batam unukt Periode yang Berakhir 31 Desember 2020 (Unaudited). Batam: Badan Pengusahaan Kawasan Perdagangan Bebas dan Pelabuhan Bebas Batam.

Buchanan, J. M. (1963). The Economics of Earmarked Taxes. Journal of Political Economy, 71, 457-469. http://dx.doi.org/10.1086/258794

Dewi, A. A. S. I. K., \& Muliartha, K. (2021). Penerapan dan Evaluasi PSAP Nomor 13 dalam Penyajian Laporan Keuangan (Studi pada Universitas Pendidikan Ganesha). E-Jurnal Akuntansi Udayana, 31(2), 476-489. https://doi.org/10.24843/EJA.2021.v31.i02.p02

Katadata. (2019). Inilah Badan Layanan Umum Dengan Target Pendapatan Terbesar 2019. Databoks. https://databoks.katadata.co.id/datapublish/2019/02/26/inilah-blu-dengantarget-pendapatan-terbesar-2019

Keputusan Kepala Badan Pengusahaan Kawasan Perdagangan Bebas dan Pelabuhan Bebas Batam Nomor 134 Tahun 2020 tentang Pembayaran Uang Wajib Tahunan Secara Cicilan dan Keringanan Sanksi Perpanjangan Alokasi Lahan pada masa Bencana Nasional Corona Virus Disease 2019.

Keputusan Presiden Republik Indonesia Nomor 25 Tahun 2005 Tentang Perubahan Kelima Atas Keputusan Presiden Republik Indonesia Nomor 41 Tahun 1973 Tentang Daerah Indutri Pulau Batam.

Keputusan Presiden Nomor 8 Tahun 2016 tentang Dewan Kawasan Perdagangan Bebas dan Pelabuhan Bebas Batam.

Kivistö, J. (2008). An assessment of agency theory as a framework for the governmentuniversity relationship. Journal of Higher Education Policy and Management, 30(4), 339-350. https://doi.org/10.1080/13600800802383018 


\section{JURNALKU}

Volume 1 No. 2, Juni 2021

Komite Standar Akuntansi Pemerintah (2016). Buletin Teknis Nomor 23 tentang Akuntansi Pendapatan Nonperpajakan. Komite Standar Akuntansi Pemerintah

McCleary, W. (1991). The Earmarking Of Goverment Revenue. The International Bank for Reconstruction and Development, 6(1), 81-104. https://doi.org/10.1093/wbro/6.1.81

Naim, Y. J. (2019). BP Batam ingin Kampung Tua tetap masuk FTZ. Antara News. https://www.antaranews.com/berita/922065/bp-batam-ingin-kampung-tua-tetapmasuk-ftz

Peraturan Kepala Badan Pengusahaan Kawasan Perdagangan Bebas dan Pelabuhan Bebas Batam Nomor 6 Tahun 2013 tentang Sistem Akuntansi Keuangan.

Peraturan Kepala Badan Pengusahaan Kawasan Perdagangan Bebas dan Pelabuhan Bebas Batam Nomor 9 Tahun 2017 tentang Perubahan Kedua atas Peraturan Kepala Badan Pengusahaan Kawasan Perdagangan Bebas dan Pelabuhan Bebas Batam Nomor 19 Tahun 2016 tentang Jenis Tarif Layanan Pada Kantor pengelolaan Lahan Badan Pengusahaan Kawasan Perdagangan Bebas dan Pelabuhan Bebas Batam.

Peraturan Menteri Keuangan Nomor 217/PMK.05/2015 Tentang PSAP BA Nomor 13 Tentang Penyajian LK BLU.

Peraturan Menteri Keuangan Nomor 220/PMK.05/2016 tentang Sistem Akuntansi dan Pelaporan Keuangan Badan Layanan Umum (BLU).

Peraturan Pemerintah Nomor 46 Tahun 2007 tentang Kawasan Perdagangan Bebas dan Pelabuhan Bebas Batam.

Peraturan Pemerintah Nomor 71 Tahun 2010 tentang Standar Akuntansi Pemerintah.

Peraturan Pemerintah Nomor 58 Tahun 2020 Tentang Pengelolaan Penerimaan Negara Bukan Pajak.

Peraturan Pemerintah Nomor 6 Tahun 2011 Tentang Pengelolaan Keuangan pada Badan Pengusahaan Kawasan.

Simangunsong, F., \& Rohmadin, S. (2018). Reviewing the Possibility of Applying Marketing Management in Local Public Sector in Bandung Regency Indonesia. Director, 2(23), 96-118. https://doi.org/10.29064/ijma.459045

Siregar, A. H. (2018). Perubahan Tarif Uang Wajib Tahunan Badan Pengusahaan Batam Tahun 2016: Tinjauan Ekonomi Politik. JOM FISIP, 5, 1-15.

Waluyo, B. (2015). Analisis Permasalahan Pada Implementasi Pola Pengelolaan Keuangan Badan Layanan Umum. Jurnal Infoartha, 3, 27-38.

Wartini, M., Saleh, C., \& Tjahjanulin, D. (2016). Pelaksanaan Pernyataan Standar Akuntansi Pemerintah No. 13 (PSAP 13) tentang Penyajian Laporan Keuangan Badan Layanan Umum di Perguruan Tinggi Negeri (Studi pada Badan Layanan Umum Universitas Brawijaya). Jurnal Ilmiah Administrasi Publik (JIAP), 2(1), 58-67. https://doi.org/10.21776/ub.jiap.2020.006.01.7

Wibowo, P., \& Varikha, N. (2018). Transformasi Pelaporan Keuangan Basis Akrual pada Politeknik Keuangan Negara STAN: Sudahkah Tuntas? Substansi: Sumber Artikel Akuntansi Auditing Dan Keuangan Vokasi, 2(1), 97. https://doi.org/10.35837/subs.v2i1.276

Muhammad Zaenuddin, Kumorotomo, W., Saleh, S., \& Hadna, A. H. (2017). Praktek Otonomi Daerah di Batam: Dinamika dan Permasalahan Penerapan Kebijakan Free Trade Zone (FTZ). Seminar Nasional Cendekiawan, 125-139. http://www.trijurnal.lemlit.trisakti.ac.id/index.php/semnas/article/view/2173. 